\title{
14
}

\section{Design of a Constructed Wetland for the Treatment of Glycol Contaminated Stormwater}

\author{
Robert Flindall and Darshan S. Basran
}

The applicability of treatment wetlands for reducing the concentration of ethylene glycol is being considered at several airports, including Cincinnati and Chicago in the United States, and is being pilot-tested at the Airborne Express airport in Wilmington, Ohio and Heathrow Airport in London, England. The types of treatment wetlands being considered or implemented at these sites are surface flow and subsurface flow systems.

The Greater Toronto Airports Authority (GTAA) is constructing the first full-scale vertical-flow treatment wetland in Canada for reduction of ethylene glycol in stormwater. A two-cell treatment wetland preceded by a sedimentation forebay is under construction. The wetland facility collects water discharged from terminal aprons, taxiways, and runways where aircraft receive de-icing compounds particularly glycol. The facility provides 24 to $48 \mathrm{~h}$ of retention to attenuate storm flows and provide removal of suspended sediment. Microbial metabolism of glycol within the wetland system is expected to reduce the BOD of discharged water. Cell No.1 of the wetland is a subsurface verticalflow system and Cell No.2 is a surface horizontal-flow system. Both treatment cells will be planted with Phragmites australis reeds. This emergent hydrophyte is able to withstand the periodic flooding conditions characteristic of a stormwater management system. In addition, the reeds provide oxygen transfer to the subsurface microbe population and maintain hydraulic conductivity in the vertical-flow system. The reeds provide very little habitat benefit for gulls and waterfowl and will therefore not attract birds that may cause hazards for aircraft.

Flindall, R. and D. Basran. 2001. "Design of a Constructed Wetland for the Treatment of Glycol Contaminated Stormwater." Journal of Water Management Modeling R207-14. doi:

10.14796/JWMM.R207-14.

(C) CHI 2001 www.chijournal.org ISSN: 2292-6062 (Formerly in Models and applications to Urban Water Systems. ISBN: 0-9683681-4-X) 
The level of treatment in the wetland system will be variable because of the nature of event flows. The water quality of effluent discharged from the facility is monitored automatically using an online TOC (total organic carbon) analyzer. The GTAA uses a previously established relationship between TOC and BOD (biological oxygen demand) to determine if the effluent quality is acceptable for discharge to the adjacent watercourse. If the TOC:BOD concentrations exceed the discharge criteria for the creek, effluent is diverted to a sanitary sewer. The mass glycol loading reduction using a vertical-flow treatment wetland, especially during low-flow and high-concentration events, is expected to be significant and will contribute to the improvement in the water quality of Etobicoke Creek and provide a cost savings to the GTAA with respect to sewer use charges.

\subsection{Constructed Reed Bed Treatment Systems}

Constructed wetlands mimic the treatment conditions found in natural wetlands, but being constructed, they provide the flexibility of being located where they are required. Reed bed treatment systems have become popular in the United Kingdom and Europe for secondary treatment of domestic wastewater from rural populations ranging from a single house up to several thousand people. In Canada, the USA and Australia, constructed wetlands are more commonly used to treat stormwater, acid mine waste drainage, landfill leachate, agricultural runoff, pulp and paper wastewater, and to provide tertiary treatment for sewage treatment plants effluent and sludge drying (Pries, 1994).

Constructed wetlands and reed beds are design and man-made systems which are intended to simulate the treatment that has been observed to occur when polluted water is discharged into naturally occurring wetlands. Natural systems have been observed to improve the quality of water by removing organic matter (BOD), oxidizing ammonia, reducing nitrate, and removing phosphorous, metals and pathogens. The mechanisms are complex and involve bacterial oxidation, filtration, sedimentation and chemical precipitation.

\subsubsection{Types of Constructed Wetland Systems}

Wetland treatment systems use rooted, water-tolerant plant species and shallow flooded or saturated soil conditions to provide various types of wastewater treatment (Kadlec and Knight, 1995). The three main types of constructed wetlands are surface-flow wetlands, horizontal-flow root zone systems, and vertical-flow root zone systems. 
Surface-flow wetlands are densely vegetated and typically have permanent water depths less than $0.4 \mathrm{~m}$. Open water areas are frequently incorporated into the design to optimize hydraulics through flow spreading, and to provide wildlife habitat if enhanced habitat is desired. Typical loading rates for constructed surface-flow wetlands are $2-14 \mathrm{ha} / 1000 \mathrm{~m}^{3} /$ day.

Subsurface-flow wetlands use a bed of granular material or soil as a substrate for growth of rooted wetland plants. Wastewater flows by gravity either horizontally or vertically through the bed substrate where it comes in contact with facultative microbes living in association with the substrate and plant roots. Bed depth in horizontal-flow subsurface systems is typically less than $0.6 \mathrm{~m}$, while vertical-flow systems are typically less than $0.9 \mathrm{~m}$ in depth. Typical loading rates for constructed subsurface horizontal-flow wetlands are $0.5-5 \mathrm{ha} / 1000 \mathrm{~m}^{3} /$ day. Vertical-flow systems can tolerate larger loading than horizontal flow systems.

The plant species used in constructed wetlands include the common reed (Phragmites australis), cattail (Typha spp.), and bulrushes (Scirpus spp.). In the UK the most common plant used is Phragmites australis. This plant is able to pass oxygen down through its stem structure into the rhizomes and out through the roots (Cooper et al., 1996). It has been shown that in the area around the rhizome, the bacterial populations are enhanced.

The wetland treatment system designed for the GTAA has two treatment cells. The first treatment cell is a subsurface vertical-flow system, and the second is a surface horizontal-flow system. The cells work in parallel depending on the rate of stormwater inflow. The subsurface vertical-flow and surface horizontal-flow systems were chosen to optimize treatment and capital costs for the wide range of hydraulic and glycol-loading conditions expected from the airport stormwater system. The vertical-flow system is intended to treat run-off from smaller storm events when the glycol concentration in runoff is expected to be higher. The surface-flow system is employed during larger volume runoff events when dilution is expected to decrease to the glycol concentration in the stormwater.

\subsection{Airport Stormwater Management Objectives}

Airport operations at L.B. Pearson International Airport generate pollutants that are unique to airport activities. Of primary interest are pollutants generated by aircraft de-icing and anti-icing operations (glycol solutions), runway de-icing operations (urea, sand) and runway cleaning operations (rubber, and rubber removing compounds). Additional surface pollutants are generated from fire fighting compounds, fuel and oil spills. 
Application of the de-icing and anti-icing agents at the airport is heavily dependent on weather. Ice conditions hazardous to aircraft are most frequent when the temperature is near the freezing point combined with precipitation in the form of rain, freezing rain or snow. These pollutant loadings are seasonal, and generally occur from November to April. Rubber is left on the runways from aircraft tires, primarily when landing. Rubber build-up on the runways is removed, when required, with chemicals that are used to soften and debond the rubber. The rubber is then removed from the runway by a high-pressure water spray, and washed onto the adjacent grassed areas. Fuel spills, as well as oil and grease also affect the water quality of runoff at the airport. These spills generally occur in and around the terminal apron areas where most of the fuel is handled and loaded onto aircraft. Fire fighting chemicals may be used throughout the airport. Accumulated surface dirt, dust and sand are found in all stormwater runoff. Airport operations including heavy equipment operations and apron and taxiway sanding contribute particulate matter to runoff.

During the de-icing season (November through May) BOD concentrations in the stormwater entering the facility can exceed $2200 \mathrm{mg} / \mathrm{L}$. In the past two years (1998 and 1999) the average concentration during an exceedence event was $258 \mathrm{mg} / 1$ and $400 \mathrm{mg} / \mathrm{L}$ respectively.

Removal of these pollutants from the runoff to acceptable levels is the goal of stormwater management programs undertaken at the airport. Biological oxygen demand (BOD) is the indicator used to determine if stormwater is acceptable for discharge to the Etobicoke Creek. The allowable discharge concentration of BOD is $100 \mathrm{mg} / \mathrm{L}$.

\subsubsection{Facility Sizing}

L.B. Pearson International Airport is currently undergoing significant expansion and improvement. Expansion has included construction of runways and taxiways. Improvements include new in-field facilities such as a centralized deicing facility and construction of new passenger terminal buildings. As part of the redevelopment process new stormwater management facilities are being constructed and existing facilities are being expanded. The Etobicoke Creek Stormwater Control Facility is one of the existing facilities that are currently being expanded. In addition to expanding the volume of the facility the GTAA has decided to redesign the facility as a constructed wetland.

The new stormwater management facility receives drainage from a drainage area of approximately $382 \mathrm{ha}$. This area includes Terminal One and approximately half of the new in-field development area. Ultimately this drainage catchment will be $70 \%$ to $80 \%$ impervious area due to construction 
of new facilities and runways. The criterion used for sizing the required storage volume is $24-48 \mathrm{~h}$ detention of runoff from a $25-\mathrm{mm}$ rainfall event. The $25-$ $\mathrm{mm}$ storm approximates the 1-y return period storm event, and was chosen to achieve water quality improvements (sediment removal) and erosion control. The total storage volume of the facility is approximately $58,000 \mathrm{~m}^{3}$.

The airport storm sewer and ditch system is sized to convey flows for a 10-y return period storm. The design of the Etobicoke Creek Stormwater Control Facility includes upstream diversion of all flow rates greater than the peak flow rate expected for the $25-\mathrm{mm}$ storm event. The flows bypass the new facility and are discharged directly to the creek.

During the design stage, it was decided to incorporate a constructed wetland into the final design. The cost of diverting large volumes of glycolcontaminated stormwater to the sanitary sewer for treatment was one of the deciding factors. Considerable cost savings can be realized if BOD concentrations are reduced such that stormwater can be released to the Etobicoke Creek during the de-icing season. Since the available space for the facility was constrained by existing and future facilities, the constructed wetland had to be fit into the footprint of the storage pond.

\subsubsection{Expected Facility Performance}

Very little data exists regarding the performance of a subsurface vertical-flow reed bed system. More data is available for traditional surface horizontal-flow systems and subsurface horizontal flow systems. The typical removal efficiency for $\mathrm{BOD}_{5}$ in wetland treatment systems in North America is $73 \%$ removal (Kadlec and Knight, 1995). The typical removal efficiency for total suspended solids (TSS) is $71 \%$. Similar removal efficiencies for the facility have been calculated for the proposed facility based on the Kadlec-Knight k-C* model. Assuming the anticipated removal efficiencies for BOD, the new facility should only experience 2-3 exceedences per year of the 100-mg/L BOD criteria.

\subsection{Facility Design and Description}

The constructed wetland facility has five major components: upstream flow diversion; a sediment forebay; a subsurface vertical-flow reed bed; a surface horizontal-flow reed; and flow control. The key elements of each of these components are described in the following sections. A generalized flow schematic of the facility is shown in Figure 14.1. 

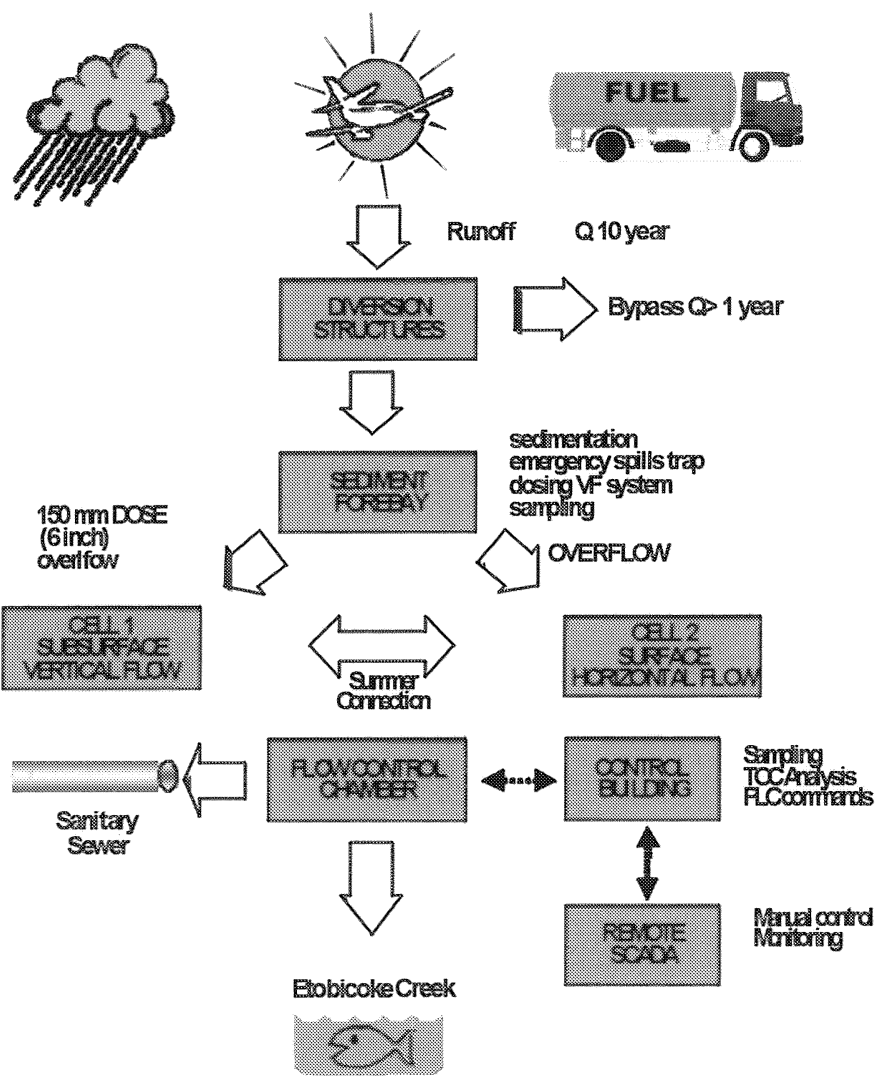

Figure 14.1 Generalized flow schematic of the treatment facility.

\subsubsection{Upstream Diversion}

The wetland facility is sized to treat runoff from a $25-\mathrm{mm}$ storm event. Any flow rate greater than the peak flow rate from the $25-\mathrm{mm}$ event is bypassed around the pond. Flow diversion is achieved by construction of diversion chambers in the conveyance system upstream of the facility. Orifice sizing controls the flows into the wetland. Once the water level in the diversions structures exceeds the design head of the orifice, diversion weirs become activated, bypassing the additional flow. The concentration of glycol is not expected to be high in runoff from the larger storm events because de-icing would generally not be required during high intensity rainstorms, and due to dilution of glycol when the runoff volumes are greater. 


\subsubsection{Sediment Forebay}

A key component of the facility is the sediment forebay. The forebay provides temporary storage of all flows entering the facility. The temporary storage in the forebay is critical to the function of the facility. Storage in the forebay allows removal of some of the sediment load in the runoff. Pretreatment to remove sediment is important for preventing blockage of the vertical flow reed bed. Secondly, storage of flows in the forebay allows intermittent dosing of the vertical-flow reed bed, which is an important design feature of the vertical-flow system. Dosing of flows from the forebay into the vertical-flow cell (Cell No.1) is achieved by opening a motorized sluice gate. The sluice gate can be closed with a command from a remote centralized location to trap accidental spills in the forebay.

The sediment forebay is lined with a concrete slab to allow easy removal of sediment build-up and trapped fuel/oil spills.

\subsubsection{Subsurface Vertical-Flow Reed Bed}

The constructed wetland is composed of two treatment cells. Cell No.1 is a subsurface vertical-flow reed bed. Cell No.2 is a surface horizontal-flow reed bed. The facility is designed to take advantage of the superior BOD reduction capabilities of the vertical-flow system by directing runoff with high glycol concentrations into Cell No.1. The surface area of Cell No.1 is 0.42 ha.

Figure 14.2 shows a section through the vertical-flow reed bed of Cell No.1. The bed consists of layers of graded gravel on top of larger stones. The reeds are planted in a layer of coarse sand which provides a level top surface. The system is drained by perforated-pipes at the invert of the cell. Water travels downward from the surface through the root zone and is collected in the drainage pipes. During this passage the glycol-laden water will come in contact with a series of aerobic, anoxic and anaerobic zones. The treatment mechanism is the same as in a conventional wastewater treatment process, i.e. oxidation of organic matter by heterotrophic bacteria; oxidation of ammonium nitrogen to nitrate by autotrophic nitrifiers; and under anoxic conditions the breakdown of nitrate through nitrite and finally into nitrogen gas by heterotrophic bacteria (Cooper et al.,1996).

The stormwater treated in Cell No.1 is dosed onto the surface of the reed bed via the motorized sluice gate in the retention wall separating the sediment forebay from Cell No.1. Each dose of water is spread evenly over the surface of the reed bed by a series of flow distribution channels. The frequency of dosing is timed such that the previous dose of water has had time to percolate through the bed and the void spaces in the granular materials are filled with air 


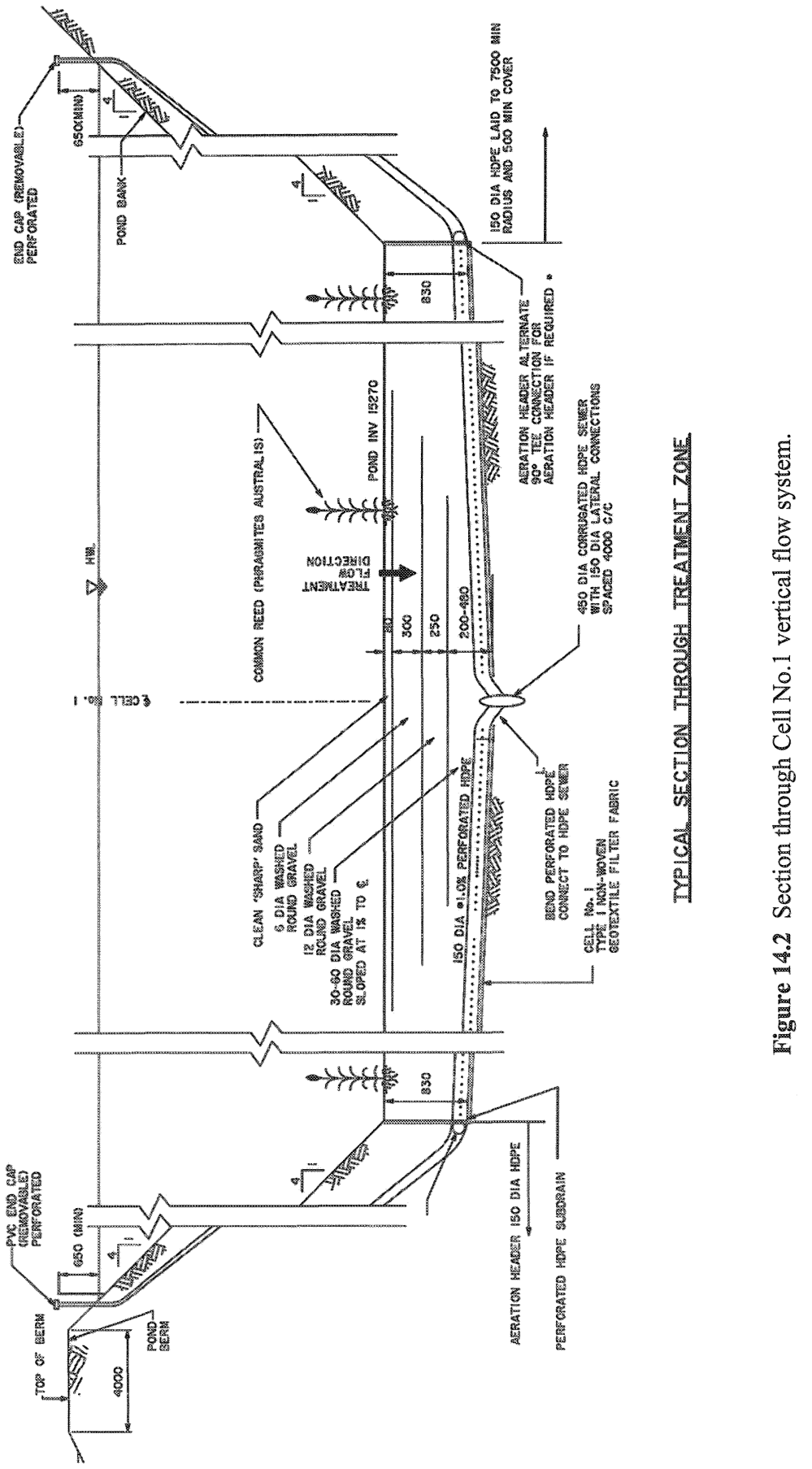


again. The next dose of water floods the surface and traps the air in the bed. This trapped air, along with the turbulence in the flow distribution system leads to good oxygen transfer into the reed bed.

The bacteria responsible for BOD removal and nitrification are in the biofilm growing on the sand and gravel particles. The Phragmites growing in the bed provide some oxygen transfer through their aerenchymous plant tissue, but their main purpose is to help maintain the hydraulic conductivity of the bed. The oxygen requirements of the bacteria are met through the dosing. Total oxygen transfer has been reported to be as high as 30-150 $\mathrm{g} \mathrm{O}_{2} / \mathrm{m}^{2} / \mathrm{d}$ depending on the granular matrix (Cooper et al.,1996). Oxygen availability is not the limiting factor in fully drained vertical-flow systems. Rather microbial kinetics and hydraulic flow rates through the media are the controlling factors in BOD removal.

The hydraulic conductivity of the sand layer is the limiting factor in the design of vertical flow systems. The vertical-low system is designed with a dosing rate of $150-\mathrm{mm} / \mathrm{h}$ over the area of the reed bed. The time to deliver a volume equivalent to a $150-\mathrm{mm}$ depth over the surface of the cell varies with the hydraulic head available in the sediment forebay, and varies from 4 to $16 \mathrm{~min}$.

\subsubsection{Surface Horizontal-Flow Reed Bed}

Cell No.2 of the facility is the more common surface-flow reed bed or traditional wetland. It is also planted with Phragmites. The hydraulic operation of the facility is such that the sediment forebay overflows into Cell No.2 once the forebay reaches its maximum storage capacity. This arrangement directs stormwater with lower expected glycol concentrations into Cell No.2, and higher concentrations into Cell No.1. Cell No.2 has more than 3 times the surface area of Cell No.1 (1.38 hectares) and is primarily intended for storage of runoff rather than treatment.

Cell No. 2 is normally flooded to a depth of $0.10-0.15 \mathrm{~m}$. The reed bed has deep zones at either end and at the mid-point spanning the width of the facility. These deep zones act as flow spreaders to equalize loadings across the reed bed. Discharge of water from Cell No.2 is via an open orifice that allows the ponded water in the cell to be totally drained in $24 \mathrm{~h}$.

The fact that Phragmites can transfer oxygen from the atmosphere to the root zone is important for the treatment that occurs in the surface-flow red bed. Lenticels or small openings in the above- water portions of the stems of the plants provide an entry point for oxygen into the vascular tissue of the plant. The oxygen transfer through the lenticels and aerenchymous tissue has been measured between $2.08 \mathrm{~g}$ to $5-12 \mathrm{~g} \mathrm{O}_{2} / \mathrm{m}^{2} / \mathrm{d}$ (Kadlec and Knight, 1995). 


\subsubsection{Flow Control}

The final component of the system is analysis of the effluent and flow control. As noted previously, the discharge criteria for effluent entering Etobicoke Creek from the facility is $100-\mathrm{mg} / \mathrm{L}$ of BOD. Effluent with concentrations above this level can only be discharged to the sanitary sewer. Effluent from each cell is directed into a multi-compartment chamber. Discharges from each cell can be controlled through the opening and closing of sluice gates in the chamber.

Normally effluent from both treatment cells is combined in the Flow Control Chamber and discharged to Etobicoke Creek. This effluent is analyzed for Total Organic Carbon (TOC) content. A predetermined relationship between TOC and BOD allows scaling of the TOC values to BOD concentrations. The use of an on-line TOC analyzer allows real-time control of the facility rather than waiting for the results of the BOD5 analysis from a laboratory.

If the TOC:BOD concentration is above the acceptable limit, then the gatevalve outlet to the creek is closed and effluent from each of the treatment cells is analyzed separately. The TOC analysis of each separate effluent stream will determine if one or both treatment cells is contributing high BOD effluent. The cell or cells with high BOD concentrations can then be isolated by closing sluice gates in the flow control chamber. The effluent with high BOD is only discharged to the sanitary sewer following a manual command from the facility operator.

\subsection{Conclusions}

The Etobicoke Creek Stormwater Control Facility is currently under construction. The reed beds are expected to be planted in May 2000. The reed beds should have fully established vegetative coverage within two growing seasons. At that time the treatment efficiency of the facility can be assessed.

\section{References}

CH2M Gore \& Storrie Limited, 1996. Phase II - Stormwater Management Master Plan, Lester B. Pearson International Airport, Toronto, Ontario. Prepared for Transport Canada

Cooper, P.F., Job, G.D., Green, M.B., and Shutes R.B.E., 1996. Reed Beds and Constructed Wetlands for Wastewater Treatment WRc Swindon, Frankland Road, Blagrove Swindon, Wiltshire, United Kingdom, SN5 8YF, ISBN 1-89892027-3, 183 pp. 
Kadlec, R.H. and Knight, R.L., 1995. Treatment Wetlands CRC Press LLC, 2000 Corporate Blvd., N.W., Boca Raton, Florida, U.S.A. 33431, ISBN 0-87371-930-1, 893 pp.

Pries, J. 1994. Wastewater and Stormwater Applications of Wetlands in Canada Secretariat to the North American Wetlands Conservation Council (Canada), Suite 200, 1750 Courtwood Crescent, Ottawa, Ontario, Canada K2C 2B5, ISBN 0662-22767-0, 66 pp.

Water Pollution Control Federation, 1990. Wetland Systems. Chapter9. In Natural Systems for Waste Water Treatment: Manual of Practice. Report No. FD-16. Alexandri, Virginia,USA.

Winter Associates and Gore \& Storrie Limited, 1991 Lester B. Pearson International Airport, Airside Development Project - Stormwater Analysis Final Report No.16. Prepared for Pubic Works Canada and Transport Canada 
